\title{
Base-free oxidation of 5-hydroxymethyl-2-furfural to 2,5-furan dicarboxylic acid over basic metal oxide-supported ruthenium catalysts under aqueous conditions
}

\author{
CHURCHIL ANGEL ANTONYRAJ ${ }^{\mathrm{a}}$, NHAN THANH THIEN HUYNH ${ }^{\mathrm{a}, \mathrm{b}}$, \\ KYUNG WON LEE ${ }^{a, c}$, YONG JIN KIM ${ }^{\mathrm{a}, \mathrm{b}}$, SEUNGHAN SHIN ${ }^{\mathrm{a}, \mathrm{b}}$, JONG SHIK SHIN ${ }^{\mathrm{c}}$ and \\ JIN KU CHO $\mathrm{CH}^{\mathrm{a}, \mathrm{b}, *}$ \\ ${ }^{a}$ Green Chemistry and Engineering R\&D Department, Korea Institute of Industrial Technology (KITECH), \\ 89 Yangdaegiro-gil, Ipjang-myeon, Seobuk-gu, Cheonan, Chungnam 331-822, Korea \\ ${ }^{b}$ Department of Green Process and System Engineering, Korea University of Science and Technology (UST), \\ 89 Yangdaegiro-gil, Ipjang-myeon, Seobuk-gu, Cheonan, Chungnam 331-822, Korea \\ ${ }^{\mathrm{c}}$ Department of Biotechnology, Yonsei University, 50 Yonsei-ro, Seodaemun-gu, Seoul 120-749, Korea \\ E-mail: jkcho@kitech.re.kr
}

MS received 10 May 2018; revised 13 August 2018; accepted 1 September 2018; published online 30 October 2018

\begin{abstract}
Polyethylene terephthalate (PET) is the third-largest globally produced polymer, and many efforts have been made to replace PET with a renewable polymer. One renewable alternative to PET is polyethylene furanoate (PEF), which is prepared using 2,5-furan dicarboxylic acid (FDCA) as a precursor instead of terephthalic acid (TPA). Biomass-derived hydroxymethyl-2-furfural (HMF) can be converted to 2,5-furan dicarboxylic acid (FDCA) through multiple oxidation reactions. Metal oxide-supported Ru catalyst prepared by simple methods for the oxidation of 5-hydroxymethylfurfural (HMF) to 2,5-furan dicarboxylic acid (FDCA) in the absence of a base under aqueous conditions is reported. This study clearly explains that the nature of basicity of the support has an important role on the selective oxidation of HMF to FDCA. Among the various materials studied magnesium oxide (MgO)-supported Ru catalyst afforded a 100\% HMF conversion and more than $90 \%$ FDCA yield with 90 psi of $\mathrm{O}_{2}$ at $160^{\circ} \mathrm{C}$ in $4 \mathrm{~h}$ and it could be used 5 times without a significant drop of FDCA yields.
\end{abstract}

Keywords. Ruthenium; metal oxides; base-free oxidation; aqueous conditions; 5-hydroxymethylfurfural (HMF); 2,5-furan dicarboxylic acid (FDCA).

\section{Introduction}

The diminishing availability of petroleum resources is an increasing problem for the production of energy and chemicals that are essential for society. The worldwide reserves of petroleum resources are expected to be sufficient for another 40 years, which increased concerns about rising oil prices. ${ }^{1}$ Biomass is the term used to describe all biological matter produced by photosynthesis using solar energy, and biomass is an alternative to petroleum resources. Abundant biomass resources are a promising alternative for the sustainable supply of valuable intermediates to chemical industries for the production of drugs and polymeric materials. ${ }^{2}$ "Roadmap of Biomass Technologies," a report authored by 26 leading experts, predicted that by 2030, $20 \%$ of transportation fuels and $25 \%$ of chemicals will be produced from biomass. ${ }^{3}$ Plant biomass is a labourintensive and land-intensive resource with a variable economy due to rapidly growing utilization for the production of fuels and chemicals. ${ }^{4}$ Plant biomass-derived carbohydrates can be converted into fuels and chemicals via fermentation to bioethanol, enzyme-catalyzed conversion to hydrogen and anaerobic digestion to

\footnotetext{
*For correspondence

Electronic supplementary material: The online version of this article (https://doi.org/10.1007/s12039-018-1551-z) contains supplementary material, which is available to authorized users.
} 


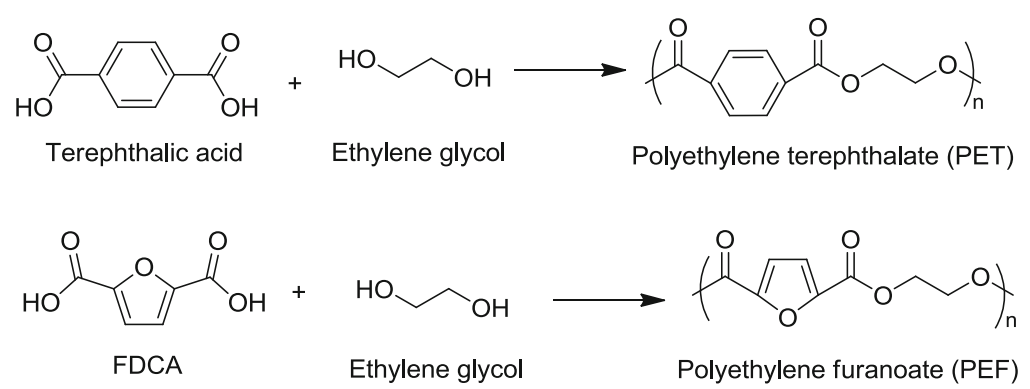

Figure 1. Synthesis of PET and PEF polymers.

methane. ${ }^{5-7}$ Every process has its own advantages and disadvantages during development, and research is ongoing to further expand the use of biomass. The conversion of carbohydrates to fuels and chemicals through 5-hydroxymethyl-2-furfural (HMF) is a catalytic method to utilize carbohydrate biomass in which oxidation leads to the replacement of polyethylene terephthalate (PET), the third-largest globally produced polymer. ${ }^{8}$ Several attempts have been made to replace PET using a renewable polymer, polyethylene furanoate (PEF), because PEF is a carbon neutral bio-based material, and its physical performance, such as glass transition temperature and gas permeability, is greater than PET (Figure 1). ${ }^{9,10}$

HMF was identified as an intermediate chemical with the potential to be converted to the PEF polymer precursor, 2,5-furan dicarboxylic acid (FDCA). FDCA is obtained by full oxidation of both the formyl and hydroxymethyl groups of HMF to a carboxylic acid. HMF can be oxidized to FDCA with quantitative amounts of conventional oxidants such as $\mathrm{KMnO}_{4}$ or $\mathrm{HNO}_{3} .{ }^{11}$ Recently, enzyme-mediated preparation methods of FDCA were reported. ${ }^{12-14}$ However, most studies focus on heterogeneous catalysis using molecular oxygen as an oxidant under aqueous conditions; furthermore, several studies supported $\mathrm{Au}$ and $\mathrm{Pt}$ catalysts for this purpose. ${ }^{15-17}$ Moreover, excess inorganic bases such as $\mathrm{NaOH}$ or $\mathrm{Na}_{2} \mathrm{CO}_{3}$ were used in some processes. ${ }^{18-21}$ Hydrotalcite-supported $\mathrm{Au}$ nanoparticles gave 99\% FDCA yield in the absence of a base, but its yield was significantly decreased during recycling. ${ }^{22}$ Several $\mathrm{Pt}$ and $\mathrm{Au}$ based catalysts found to be successful for the base free HMF oxidation but high cost of the precious metals is still an issue. ${ }^{23-26}$ Spinel oxides with active metal like cobalt and manganese were also successfully employed in this selective oxidation reaction; but in acetic acid solvent. ${ }^{27}$ Ruthenium is a potential oxidizing metal; various ruthenium supported heterogeneous catalysts were used for HMF oxidation to 2,5-diformylfuran (DFF) ${ }^{28-31}$ However, ruthenium supported materials were not successful for HMF oxidation to FDCA because complete oxidization to FDCA was impossible or ruthenium leaching caused the ruthenium to be unusable. ${ }^{32,33}$ Recently, Ru/C commercial catalyst showed the base free oxidation of HMF to FDCA with an $88 \%$ FDCA yield using high catalyst loading. ${ }^{34}$ However, such a $\mathrm{Ru} / \mathrm{C}$ catalyst needs activation before reuse. More recently, our group developed a new class of $\mathrm{MnCo}_{2} \mathrm{O}_{4}$ spinel supported $\mathrm{Ru}$ catalyst for selective oxidation of HMF into DFF or FDCA according to solvents. ${ }^{35,36}$

Here we report exploration of basic metal oxidesupported Ru catalysts to use for this important reaction in the absence of a base.

\section{Experimental}

\subsection{Materials}

Magnesium nitrate hexahydrate $\left(\mathrm{Mg}\left(\mathrm{NO}_{3}\right)_{2} \cdot 6 \mathrm{H}_{2} \mathrm{O}, 99 \%\right.$, ACS reagent), aluminium nitrate nonahydrtate $\left(\mathrm{Al}\left(\mathrm{NO}_{3}\right)_{3}\right.$. $9 \mathrm{H}_{2} \mathrm{O}, \geq 98 \%$, ACS reagent), sodium hydroxide $(\mathrm{NaOH}, \geq$ $97 \%$, ACS reagent), sodium bicarbonate $\left(\mathrm{NaHCO}_{3}, \geq 99.7 \%\right.$, ACS reagent), ruthenium(III) chloride $\left(\mathrm{RuCl}_{3}, \mathrm{Ru}\right.$ content 45-55\%), 5-hydroxymethyl-2-furfural (HMF, 99\%), MgAlhydrotalcite $\left(\mathrm{Mg}_{6} \mathrm{Al}_{2}\left(\mathrm{CO}_{3}\right)(\mathrm{OH})_{16} \cdot 4 \mathrm{H}_{2} \mathrm{O}\right), \mathrm{MgO}(97 \%$, ACS reagent), $\mathrm{ZrO}_{2}$ (powder, $99 \%$ trace metals basis), $\mathrm{CeO}_{2}$ (powder, $99.995 \%$ trace metals basis) and $\mathrm{La}_{2} \mathrm{O}_{3}(99.99 \%$ trace metals basis) were purchased from Sigma-Aldrich (USA). All chemicals were directly used without further purification unless otherwise mentioned.

\subsection{Methods}

Powder X-ray diffraction (PXRD) was carried out on a Bruker M18XHF22 system using Cu K $\alpha$ radiation $(\lambda=1.54056 \AA)$. The operating voltage and current were $40 \mathrm{kV}$ and $40 \mathrm{~mA}$, respectively with a scanning speed of $2 \mathrm{deg} / \mathrm{min}$, for data collection. The data were processed using the XPRESS (version 1.0.3) software. Transmission electron microscope (TEM) images were taken with a Maker FEI, model Technai G2 microscope with an acceleration voltage of $200 \mathrm{keV}$ using carbon-coated 200 mesh copper grids. Total surface analysis of the materials obtained by $\mathrm{NH}_{3}$ and $\mathrm{CO}_{2}$ TPD was 
performed on an Autochem II 2920 (Micromeritics Corp.). Samples were pretreated using $\mathrm{He}$ at $100^{\circ} \mathrm{C}$ for $1 \mathrm{~h}$, continued with adsorption of $\mathrm{NH}_{3}$ or $\mathrm{CO}_{2}$ at $100^{\circ} \mathrm{C}$ for $1 \mathrm{~h}$, and followed by gas desorption from $100{ }^{\circ} \mathrm{C}$ to $800{ }^{\circ} \mathrm{C}$ (rate $10{ }^{\circ} \mathrm{C} / \mathrm{min}$ ). The specific surface area of the catalyst material was determined in a BET surface analyzer (Bruanuer-Emmett-Teller, ASAP2010, Micromeritics, USA) using $\mathrm{N}_{2}$ as the adsorbent at liquid nitrogen temperature $(77 \mathrm{~K})$ in a relative pressure (P/P0) range of 0 to 0.25 . The samples (in powder form) were degassed in the air for over $12 \mathrm{~h}$ at $100{ }^{\circ} \mathrm{C}$ prior to analysis. XPS measurements were carried out on a Thermo Fischer Scientific K-alpha using monochromatized $\mathrm{Al} \mathrm{K} \alpha$ radiation $(\mathrm{h} v=1486.6 \mathrm{eV}$ ) and processed using Thermo Avantage software. NMR analysis was performed on a Bruker Spectrospin 300 (Bruker Corporation, Germany) in a DMSO-d6 solvent. The conversion of HMF and the yield of the products, including FDCA were determined using high-performance liquid chromatography (HPLC, Agilent 1200 series) equipped with a refractive index (RI) detector and an Aminex HPX-87H column (Bio-Rad Laboratories, Inc.). The HPLC analysis conditions were as follows: eluent, $0.01 \mathrm{~N} \mathrm{H}_{2} \mathrm{SO}_{4}$; flow rate, $0.6 \mathrm{~mL} / \mathrm{min}$; and column temperature, $45^{\circ} \mathrm{C}$. Prior to the HPLC analysis, all samples were subjected to dilution with water (HPLC grade) to prevent signal overload and damage to the system.

\subsection{Synthesis of $\mathrm{MgAlO}$}

The material was prepared by co-precipitation under low supersaturation. In this method, two solutions, namely, solution (A) containing the desired amount of magnesium and aluminium nitrates and solution (B) having precipitating agents (i.e., $\mathrm{NaOH}$ and $\mathrm{Na}_{2} \mathrm{CO}_{3}$ ) were added slowly $(1 \mathrm{~mL} / \mathrm{min})$ and simultaneously using Schott electronic titrator, at a constant pH 9.5 during addition under vigorous stirring at room temperature. The addition took approximately $90 \mathrm{~min}$ and the final $\mathrm{pH}$ was adjusted to 10 by adding few drops of precipitant solution. The samples were aged in the mother liquor at $65^{\circ} \mathrm{C}$ for $18 \mathrm{~h}$ in an oil bath, filtered, washed (until total absence of nitrates and sodium in the washing liquids) and dried in an air oven at $100-110^{\circ} \mathrm{C}$ for $12 \mathrm{~h}$. This was calcined at $500{ }^{\circ} \mathrm{C}$ for $2 \mathrm{~h}$ and named as $\mathrm{MgAlO}$.

\subsection{Ruthenium impregnation}

Ruthenium was loaded on the support using wet impregnation method like the calculated amount of $\mathrm{RuCl}_{3}$ (to achieve $2 \mathrm{wt} \%$ metal) was dissolved in $100 \mathrm{~mL}$ of water to which $2 \mathrm{~g}$ of support (MgAlO prepared above or other metal oxides purchased) was added and stirred at room temperature for $3 \mathrm{~h}$. Filtered and washed with copious amount of water and dried in a vacuum oven at $30^{\circ} \mathrm{C}$.

\subsection{Catalytic reactions}

All the reactions were carried out in a $50 \mathrm{~mL}$ Parr reactor; HMF, solvent, and catalyst were added and the reactor was fleshed with $\mathrm{O}_{2}$ for 3 times. Pressurized with $\mathrm{O}_{2}$ again and heated up to the desired temperature to achieve the operating pressure; all the reactions were carried for $4 \mathrm{~h}$ with $650 \mathrm{rpm}$ stirring. Immediately after the reaction reactor was cooled to room temperature and samples were analyzed with HPLC.

\section{Results and Discussion}

Ruthenium was simply loaded on the metal oxides using wet impregnation method as reported previously. ${ }^{29}$ PXRD patterns of the synthesized $\mathrm{Ru} /$ metal oxides were the same as the metal oxides reported in the literature. No reflection was observed for ruthenium/ruthenium oxide in these materials, implying that the ruthenium is homogeneously loaded on the support. PXRD analysis of $\mathrm{Ru} / \mathrm{MgAlO}$ and $\mathrm{Ru} / \mathrm{MgO}$ showed mixed metal oxide and metal oxide phase and the right formation of mixed metal oxide $\mathrm{MgAlO}$ could be verified. $\mathrm{Ru} / \mathrm{La}_{2} \mathrm{O}_{3}$ contains pure $\mathrm{La}_{2} \mathrm{O}_{3}$ phase along with some $\mathrm{La}(\mathrm{OH})_{3}$ impurity phase. $\mathrm{Ru} / \mathrm{ZrO}_{2}$ and $\mathrm{Ru} / \mathrm{CeO}_{2}$ contain tetragonal zirconium phase and cubic $\mathrm{CeO}_{2}$ phase, respectively (Figure 2). To understand the morphology and nature of ruthenium loading TEM was carried out and each material exhibited different morphology (Figure S1, Supplementary Information). Ru/MgAlO showed agglomerated small platelet materials forming a sponge-like structure and $\mathrm{Ru} / \mathrm{MgO}$ showed larger platelet-like materials. $\mathrm{Ru} / \mathrm{La}_{2} \mathrm{O}_{3}$ showed agglomerated coral-like structure rather than the platelet and both $\mathrm{Ru} / \mathrm{ZrO}_{2}$ and $\mathrm{Ru} / \mathrm{CeO}_{2}$ showed distorted sphere-like structure. Presence of ruthenium over these materials was confirmed by SEM-EDX analysis.

Oxidation of HMF was performed using synthesized materials as a catalyst in a water medium (Table 1). ${ }^{19}$ HMF bears two oxidizable moieties corresponding

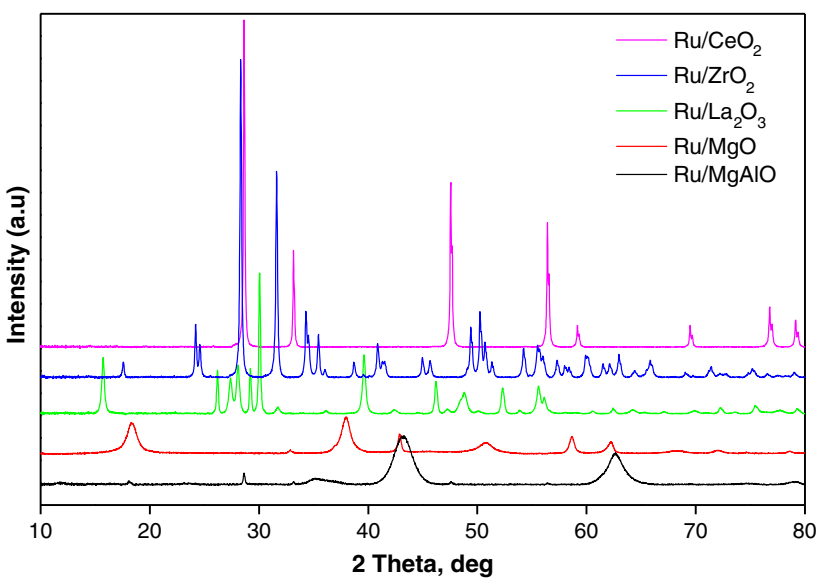

Figure 2. Powder X-ray diffraction analysis of synthesized materials (with $2 \mathrm{wt} \% \mathrm{Ru}$ loading). 
Table 1. Conversion of HMF and selectivity of products in the oxidation of HMF using a Ru catalyst supported on various metal oxides. ${ }^{\mathrm{a}}$

\begin{tabular}{llccccccc}
\hline & & & \multicolumn{5}{c}{ Yield (\%) } \\
\cline { 5 - 8 } Entry & Catalyst & HMF conversion (\%) & b & DFF & HMFCA & FFCA & FDCA & LA \\
\hline 1 & $\mathrm{Ru} / \mathrm{MgAlO}$ & 100 & 0.5 & 0 & 0.2 & 99 & 0 \\
2 & $\mathrm{Ru} / \mathrm{MgO}$ & 88 & 2.8 & 0 & 21 & 58 & 5.4 \\
3 & $\mathrm{Ru} / \mathrm{La}_{2} \mathrm{O}_{3}$ & 4.6 & 0 & 0 & 1.4 & 0.8 & 2.4 \\
4 & $\mathrm{Ru} / \mathrm{CeO}_{2}$ & 89 & 45 & 0 & 35 & 7.0 & 3.2 \\
5 & $\mathrm{Ru}_{\mathrm{ZrO}_{2}}$ & 100 & 86 & 0 & 14 & 0 & 0 \\
6 & $\mathrm{RuCl}_{3}{ }^{c}$ & 100 & 7 & 0 & 26 & 18 & 30 \\
\hline
\end{tabular}

${ }^{a}$ Reaction conditions: HMF (252 mg, $2 \mathrm{mM}$ ), catalyst (200 mg, $2 \mathrm{wt} \% \mathrm{Ru}$ ), $\mathrm{H}_{2} \mathrm{O}$ (20 mL), $\mathrm{O}_{2}(90 \mathrm{psi}), 140{ }^{\circ} \mathrm{C}, 4 \mathrm{~h}$.

${ }^{b}$ Determined by HPLC.

${ }^{\mathrm{c}}$ Equimolar to supported Ru.

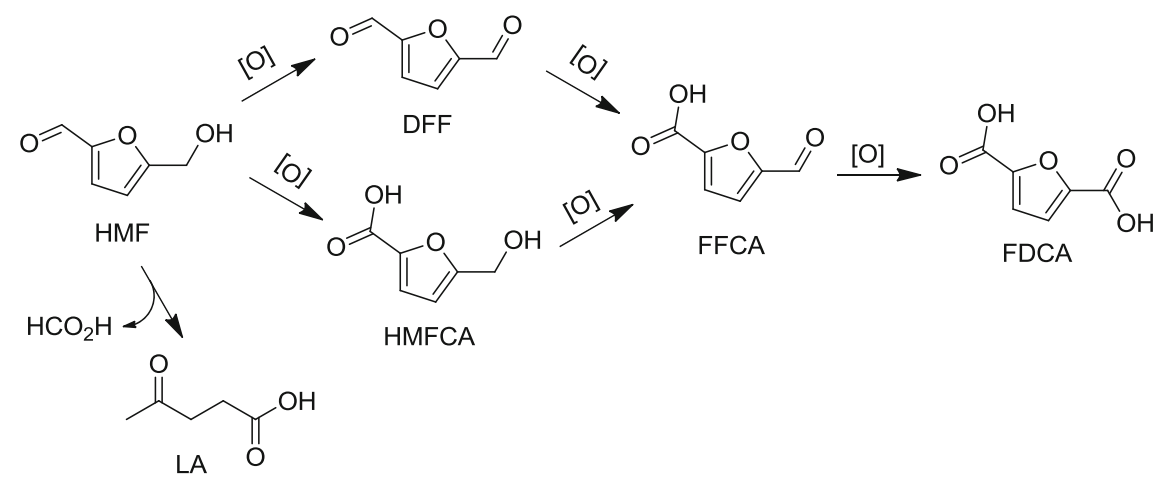

Figure 3. Oxidation pathways from HMF to FDCA.

to formyl and hydroxymethyl groups. From HMF, oxidation of the hydroxymethyl group yields DFF, while oxidation of the formyl group yields 5-(hydroxymethyl)2-furan carboxylic acid (HMFCA). Further oxidation of DFF and HMFCA can yield FDCA via 5-formyl-2-furan carboxylic acid (FFCA). Therefore, DFF, HMFCA, FFCA can be obtained as intermediates during the oxidation of HMF to FDCA (Figure 3).

Among the materials investigated, $\mathrm{MgAlO}$ support obtained from layered double hydroxide (LDH) was found to be highly active with a $100 \% \mathrm{HMF}$ conversion and a 99\% FDCA yield (Entry 1 ) ${ }^{20} \mathrm{MgO}$ supports showed high activity towards HMF conversion, but the yield of FDCA was moderate (58\%) (Entry 2). Instead, DFF and FFCA intermediates produced by the partial oxidation of HMF still remained. $\mathrm{La}_{2} \mathrm{O}_{3}$ support has a very low HMF conversion of less than $5 \%$, and a deformylated product, levulinic acid (LA), was obtained as a major product (Entry 3 ). $\mathrm{ZrO}_{2}$ support has a low yield for FDCA, but DFF and FFCA were obtained in $45 \%$ and $35 \%$ yields, respectively (Entry 4). $\mathrm{CeO}_{2}$ was not sufficient for the oxidation of HMF up to FDCA, but $\mathrm{CeO}_{2}$ was converted mainly to DFF (86\%) (Entry 5).
Homogeneous ruthenium catalyzed a reaction in the presence of $\mathrm{RuCl}_{3}$ prefers over oxidation of HMF to LA and FA rather than FDCA (Entry 6). In all supports, HMFCA was not found as an intermediate, which indicated that oxidation of HMF using metal oxidessupported $\mathrm{Ru}$ catalyst proceeds via DFF.

From these results, the order of Ru catalyst activity for HMF oxidation was determined according to supports: $\mathrm{MgAlO}>\mathrm{MgO}>\mathrm{ZrO}_{2}>\mathrm{CeO}_{2} \gg \mathrm{La}_{2} \mathrm{O}_{3}$. The surface area of these materials was measured to find the reason the activity (Table 2). The order of BET surface area of the materials were in the order of $\mathrm{Ru} / \mathrm{MgAlO}>$ $\mathrm{Ru} / \mathrm{MgO} \gg \mathrm{Ru} / \mathrm{La}_{2} \mathrm{O}_{3}>\mathrm{Ru} / \mathrm{ZrO}_{2}>\mathrm{Ru} / \mathrm{CeO}_{2}$ and it confirms that the high activity of $\mathrm{MgAlO}$ and $\mathrm{MgO}$ supports were due to its high surface area. But this analysis is not sufficient to explain the complete trend in the catalytic activity. Though these materials were different morphology as observed by TEM measurements reason for different catalytic activity might be due to different basic nature of the support.

To find the basicity of these materials temperature programmed desorption (TPD) were investigated (Table 3). TPD analysis of the catalysts indicates 
Table 2. Surface properties of synthesized materials.

\begin{tabular}{lccc}
\hline Catalyst & BET surface area $\left(\mathrm{m}^{2} / \mathrm{g}\right)$ & Pore volume $\left(\mathrm{cm}^{3} / \mathrm{g}\right)$ & Aver. pore diameter (A) \\
\hline $\mathrm{Ru} / \mathrm{MgO}$ & 73 & 0.372 & 203 \\
$\mathrm{Ru} / \mathrm{MgAlO}$ & 200 & 0.394 & 79 \\
$\mathrm{Ru} / \mathrm{La}_{2} \mathrm{O}_{3}$ & 13 & 0.051 & 156 \\
$\mathrm{Ru} / \mathrm{CeO}_{2}$ & 3.9 & 0.019 & 191 \\
$\mathrm{Ru} / \mathrm{ZrO}_{2}$ & 4.5 & 0.018 & 157 \\
\hline
\end{tabular}

Table 3. Temperature programmed desorption analysis of synthesized materials.

\begin{tabular}{|c|c|c|c|c|c|c|}
\hline \multirow[b]{2}{*}{ Name } & \multicolumn{2}{|c|}{$\mathrm{NH}_{3} \mathrm{TPD}$} & \multicolumn{2}{|c|}{$\mathrm{CO}_{2} \mathrm{TPD}$} & \multirow[b]{2}{*}{$\begin{array}{l}\text { Total acidity } \\
(\mathrm{mmol} / \mathrm{g})\end{array}$} & \multirow[b]{2}{*}{$\begin{array}{l}\text { Total basicity } \\
(\mathrm{mmol} / \mathrm{g})\end{array}$} \\
\hline & $\begin{array}{l}\text { Maximum } \\
\text { desorption }\left({ }^{\circ} \mathrm{C}\right)\end{array}$ & $\begin{array}{l}\text { Amount of } \\
\mathrm{HN}_{3}(\mathrm{mmol} / \mathrm{g})\end{array}$ & $\begin{array}{l}\text { Maximum } \\
\text { desorption }\left({ }^{\circ} \mathrm{C}\right)\end{array}$ & $\begin{array}{l}\text { Amount of } \\
\mathrm{CO}_{2}(\mathrm{mmol} / \mathrm{g})\end{array}$ & & \\
\hline \multirow[t]{3}{*}{$\mathrm{Ru} / \mathrm{MgAlO}$} & 279 & 1.66 & 195 & 4.40 & \multirow{3}{*}{1.66} & 6.02 \\
\hline & & & 217 & 0.22 & & \\
\hline & & & 346 & 1.40 & & \\
\hline \multirow[t]{3}{*}{$\mathrm{Ru} / \mathrm{MgO}$} & 293 & 1.30 & 156 & 0.08 & \multirow{3}{*}{3.10} & 6.09 \\
\hline & 354 & 1.80 & 221 & 0.11 & & \\
\hline & & & 340 & 5.90 & & \\
\hline \multirow[t]{3}{*}{$\mathrm{Ru} / \mathrm{La}_{2} \mathrm{O}_{3}$} & 314 & 0.87 & 325 & 3.40 & \multirow{3}{*}{1.49} & 5.10 \\
\hline & 473 & 0.38 & 384 & 0.30 & & \\
\hline & 645 & 0.24 & 484 & 1.40 & & \\
\hline \multirow{2}{*}{$\mathrm{Ru} / \mathrm{ZrO}_{2}$} & 313 & 0.19 & - & - & \multirow[t]{2}{*}{0.21} & 0 \\
\hline & 510 & 0.02 & & & & \\
\hline $\mathrm{Ru} / \mathrm{Ce}_{2} \mathrm{O}_{3}$ & 305 & 0.10 & - & - & 0.10 & 0 \\
\hline
\end{tabular}

that $\mathrm{Ru} / \mathrm{MgAlO}, \mathrm{Ru} / \mathrm{MgO}$, and $\mathrm{Ru} / \mathrm{La}_{2} \mathrm{O}_{3}$ have total basicity of $6.02,6.09$, and $5.10 \mathrm{mmol} / \mathrm{g}$, respectively while $\mathrm{Ru} / \mathrm{ZrO}_{2}$ and $\mathrm{Ru} / \mathrm{CeO}_{2}$ show no basic property. In addition, the $\mathrm{MgAlO}$ and $\mathrm{MgO}$ support contain only weak and moderate basic sites while $\mathrm{La}_{2} \mathrm{O}_{3}$ contains moderate and high basic sites. However, due to the presence of Lewis acidic character of lanthanum, $\mathrm{La}_{2} \mathrm{O}_{3}$ also contains moderate and high acidic sites, which can be the cause for low catalytic activity. In general, the catalyst supports with higher total basicity resulted in higher HMF conversion and FDCA yield.

Variation studies of temperature and $\mathrm{O}_{2}$ pressure were performed to understand the influence of reaction parameters on the oxidation of HMF to FDCA over $\mathrm{Ru} / \mathrm{MgAlO}$ (Figure S2, Supplementary Information). As the temperature increased, the HMF conversion increased with FDCA yield, and it was clearly explained that HMF oxidation passed through DFF and FFCA as previously mentioned. It was also clarified that $140{ }^{\circ} \mathrm{C}$ was the optimum temperature for the complete conversion of intermediates to FDCA. Pressure variation studies showed that $90 \mathrm{psi}$ of $\mathrm{O}_{2}$ pressure was enough for the complete conversion of HMF to FDCA; furthermore, it was confirmed that increase in $\mathrm{O}_{2}$ pressure did not affect the product, i.e., the formed product was stable under high-pressure conditions in presence of a catalyst. However, the $\mathrm{Ru} / \mathrm{MgAlO}$ catalyst filtered after the reaction washed with water and dried for reuse was not completely active for the consecutive cycles, which were also associated with a marginal amount of weight loss (Figure 4). ICP analysis was done for catalyst after first cycle which showed that $24.1 \% \mathrm{Ru}$ reduction which clearly indicated the leaching of the active metal. This observation was different from materials reported in the literature, i.e., Au supported hydrotalcites (MgAl-OH), which was found to have reusable multiple cycles. $^{22}$ To solve this problem, the $\mathrm{Ru} / \mathrm{MgAlO}$ catalyst was calcined at different temperatures including $500^{\circ} \mathrm{C}$, $700{ }^{\circ} \mathrm{C}$, and $900{ }^{\circ} \mathrm{C}$, and the reusability was verified (Figure 4).

As the calcination temperature increases the structure of the oxide materials changes along with their acid/base properties. However, these catalysts were not found to be reusable, and some catalyst weight loss was observed after the first use. FDCA is a compound with high acidity ( $\mathrm{p} K_{a}=2.28$ ), which can readily exchange the counter cation. Therefore, it was understood that $\mathrm{Ru}$ might be leached from the $\mathrm{MgAlO}$ support because $\mathrm{Ru}$ could be 


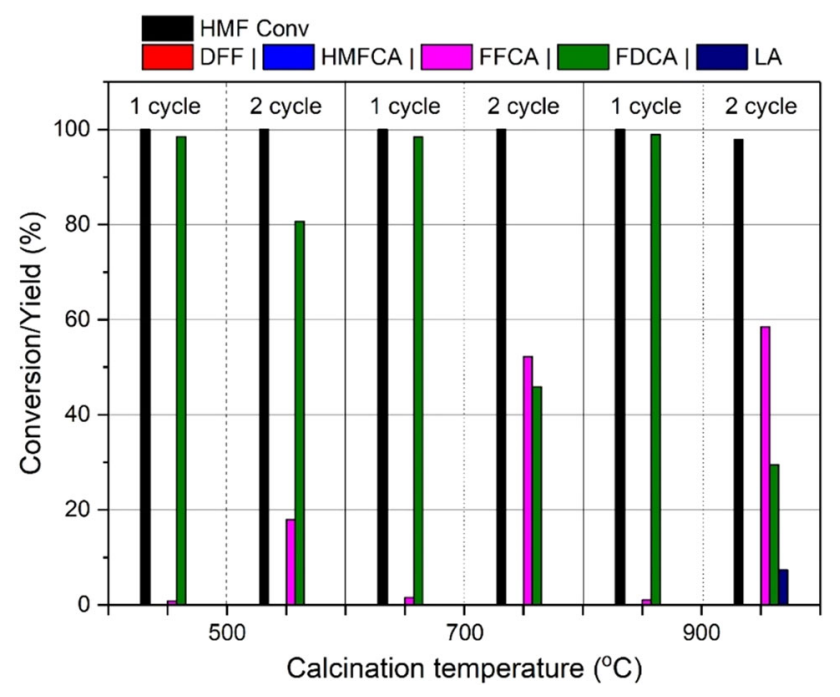

Figure 4. Reusability of the $\mathrm{Ru} / \mathrm{MgAlO}$ catalyst with different calcinations temperatures. Reaction conditions: HMF (252 mg, $2 \mathrm{mM}$ ), catalyst (200 mg, $2 \mathrm{wt} \% \mathrm{Ru}), \mathrm{H}_{2} \mathrm{O}(20 \mathrm{~mL})$, $\mathrm{O}_{2}\left(90\right.$ psi), $140{ }^{\circ} \mathrm{C}, 4 \mathrm{~h}$.

coordinated to the FDCA anion, as depicted in Figure 5. To confirm this phenomenon, commercial FDCA was stirred with a $\mathrm{Ru} / \mathrm{MgAlO}$ catalyst at $100{ }^{\circ} \mathrm{C}$ in a water solvent, and it was observed that the catalyst was dissolved in the FDCA solution.

Since $\mathrm{Ru} / \mathrm{MgAlO}$ failed to be reused for the oxidation of $\mathrm{HMF}$ to FDCA, $\mathrm{Ru} / \mathrm{MgO}$ with acceptable activity was selected for further studies. Influence of catalyst loading was examined in order to increase HMF conversion. Expectedly, the catalyst loading enhanced the HMF conversion along with FDCA yield, and $400 \mathrm{mg}$ of the catalyst was sufficient for the complete conversion of HMF with greater than $90 \%$ of FDCA yield using 90 psi of $\mathrm{O}_{2}$ in $4 \mathrm{~h}$. Further, it needs to be mentioned here that the yield of the FDCA was also high (Figure 6).

Temperature variation studies of $\mathrm{Ru} / \mathrm{MgO}$ were performed to understand the progress of the reaction (Figure 7). Its trend was similar to that of previous

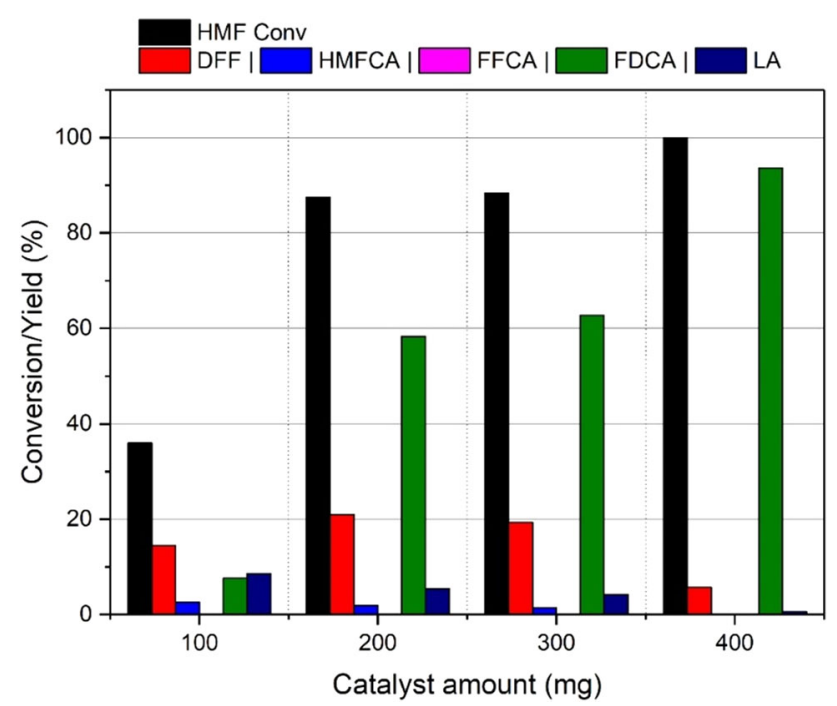

Figure 6. Influence of catalyst amount on HMF oxidation using $\mathrm{Ru} / \mathrm{MgO}$ catalyst. Reaction conditions: HMF (252 mg, $2 \mathrm{mM}), \mathrm{Ru} / \mathrm{MgO}, \mathrm{H}_{2} \mathrm{O}(20 \mathrm{~mL}), \mathrm{O}_{2}$ (90 psi), $140^{\circ} \mathrm{C}, 4 \mathrm{~h}$.

materials, and FDCA yield was reached to a maximum at a reaction temperature of $160^{\circ} \mathrm{C}$, whereas temperature over $160{ }^{\circ} \mathrm{C}$ induced decomposition of HMF took place to give considerable amounts of levulinic acid and formic acid. Decomposition products formation was also observed in reactions with high reaction temperature and lower reaction time (2 h).

To further study the reusability of these materials immediately after the reaction, the catalyst was washed with water then dried and used for the next cycle. Figure 8 shows that these materials were reusable up to 5 cycles with a relatively identical activity. To understand the nature of ruthenium species responsible for the oxidation XPS analysis was done (Figure S3, Supplementary Information). It was noticeable that XPS analysis of $\mathrm{Ru} / \mathrm{MgO}$ showed $\mathrm{Ru} 3 \mathrm{~d}_{5 / 2}$ peak at 280.5 for the fresh catalyst while for the used one this reflection was at 279.5. This change in the peak position was due to

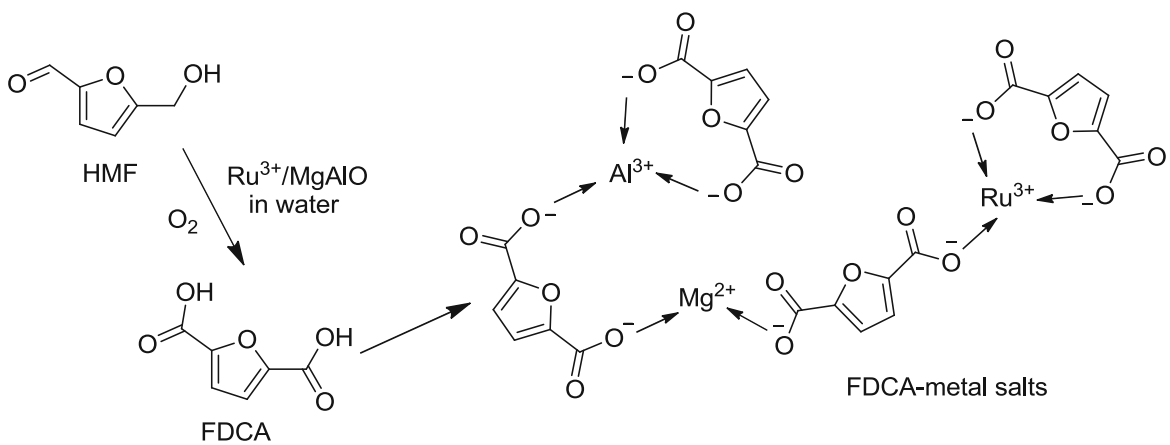

Figure 5. Proposed mechanism of leaching $\mathrm{Ru}$ and dissolving the metal oxide support. 


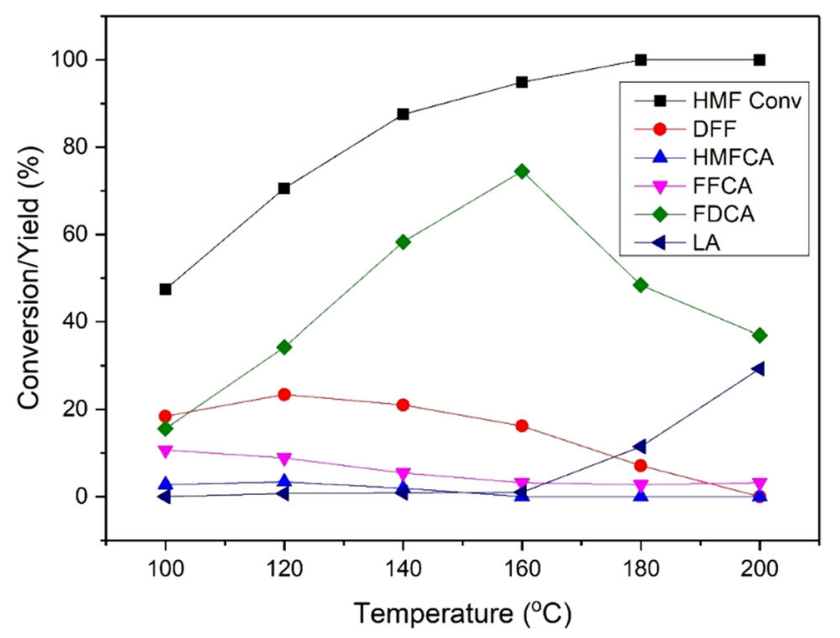

Figure 7. Influence of temperature on HMF oxidation using the $\mathrm{Ru} / \mathrm{MgO}$ catalyst. Reaction conditions: $\mathrm{HMF}$ (252 mg, $2 \mathrm{mM}), \mathrm{Ru} / \mathrm{MgO}$ (200 mg), $\mathrm{H}_{2} \mathrm{O}$ (20 mL), $\mathrm{O}_{2}$ (90 psi), 4 h.

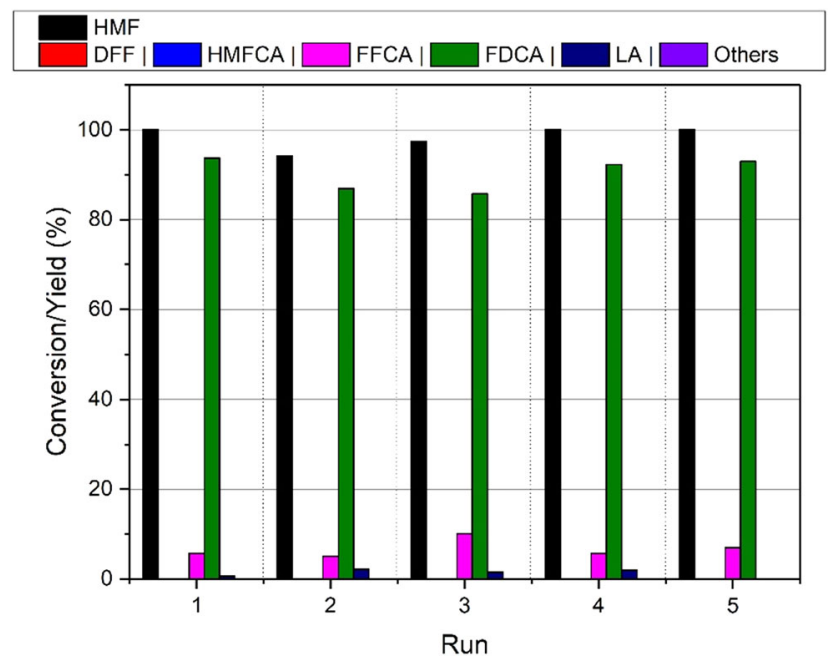

Figure 8. Reusability of the $\mathrm{Ru} / \mathrm{MgO}$ catalyst on HMF oxidation. Reaction conditions: $\mathrm{HMF}$ (252 mg, $2 \mathrm{mM}$ ), $\mathrm{Ru} / \mathrm{MgO}$ (400 mg), $\mathrm{H}_{2} \mathrm{O}(20 \mathrm{~mL}), \mathrm{O}_{2}(90 \mathrm{psi}), 160^{\circ} \mathrm{C}, 4 \mathrm{~h}$.

the electronic environment of the Ru metal was changed during the reaction but not associated with any change in the valance state of ruthenium. ${ }^{37}$

HPLC profile of the reaction mixture during and after the reaction is given in Figure S4 (Supplementary Information). This clearly shows that the FDCA was the favorable product along with some intermediate oxidation products. In the industrial process, the formed product should be purified from the reaction mixture without using much energy. The product mixture was recrystallized and the purity of the FDCA was checked using ${ }^{1} \mathrm{H}$ and ${ }^{13} \mathrm{C}$ NMR analysis (Figure S5, Supplementary Information). NMR results showed that recrystallized FDCA was pure and it can be further can be used for polymerization reaction without any further purification.

\section{Conclusion}

In conclusion, the base free oxidation of HMF to FDCA using molecular oxygen was studied over different metal oxide supported ruthenium catalysts under aqueous conditions. Basicity of the support played an important role on the complete conversion of HMF to FDCA further, the presence of Lewis acid sites in the support leads to de-formylation reaction and weak basic sites leads to formation DFF. Among the $2 \mathrm{wt} \% \mathrm{Ru}$ containing basic supports, $\mathrm{MgAlO}$ was found to be highly active; however, this support seriously dissolved during the reaction due to the highly acidic nature of the formed FDCA. On the other hand, a MgO-supported Ru catalyst, a bit less active than $\mathrm{Ru} / \mathrm{MgAlO}$, could be used 5 times with $90 \mathrm{psi}$ of $\mathrm{O}_{2}$ at $160^{\circ} \mathrm{C}$ in $4 \mathrm{~h}$ without a significant drop of FDCA yields. FDCA formed during the reaction can be easily crystallized in water and which can be directly used for additional polymerization studies without any further purification.

\section{Supplementary Information (SI)}

Supplementary data is available for TEM, TEM-EDX, HPLC, XPS, and NMR studies. Supplementary Information is available at www.iac.ac.in/chemsci.

\section{Acknowledgements}

We acknowledge financial support for this research by the Internal Research Program (PEO18030) of Korea Institute of Industrial Technology (KITECH) and this work was supported by the National Research Council of Science \& Technology (NST) grant by the Korea government (MSIP) (No. CMP-16-04-KITECH).

\section{References}

1. Chheda J N, Huber G W and Dumesic J A 2007 Liquid-phase catalytic processing of biomass-derived oxygenated hydrocarbons to fuels and chemicals Angew. Chem. Int. Ed. 467164

2. Climent M J, Corma A and Iborra S 2011 Converting carbohydrates to bulk chemicals and fine chemicals over heterogeneous catalysts Green Chem. 13520

3. https://biomassboard.gov/pdfs/final_biomass_ roadmap_2002kw.pdf: accessed on 17.05.2018

4. Demirbas A 2001 Biomass resource facilities and biomass conversion processing for fuels and chemicals Energy Convers. Manage. 421357

5. Harun R, Danquaha M K and Forde G M 2010 Microalgal biomass as a fermentation feedstock for 
bioethanol production J. Chem. Technol. Biotechnol. 85 199

6. Ghirardi M L, Zhang L, Lee J W, Flynn T, Seibert M, Greenbaum E and Melis A 2000 Microalgae: a green source of renewable $\mathrm{H}_{2}$ Trends. Biotechnol. 18506

7. Uellendahl H and Ahring B K 2010 Anaerobic digestion as final step of a cellulosic ethanol biorefinery: Biogas production from fermentation effluent in a UASB reactor-pilot-scale results Biotechnol. Bioeng. 107 59

8. van Putten R-J, van der Wall J C, de Jong E, Rasrendra C B, Heeres H J and de Vries J G 2013 Hydroxymethylfurfural, A versatile platform chemical made from renewable resources Chem. Rev. 1131499

9. Aden A and Bozell J 2004 In Top value added chemicals from biomass T Werpy and G Petersen (Eds.) (US: US Department of Energy) pp.1-76

10. Menegazzo F, Fantinel T, Signoretto M, Pinna F and Manzoli M 2014 On the process for furfural and HMF oxidative esterification over $\mathrm{Au} / \mathrm{ZrO}_{2}$ J. Catal. 31961

11. Miura T, Kakinuma H, Kawano T and Matsuhisa H 2008 Method for producing furan-2,5-dicarboxylic acid US patent 7411078

12. Dijkman W P, Groothuis D E and Fraaije M W 2014 Enzyme-catalyzed oxidation of 5hydroxymethylfurfural to furan-2,5-dicarboxylic acid Angew. Chem. Int. Ed. 536515

13. Koopman F, Wierckx N, de Winde J H and Ruijssenaars H J 2010 Efficient whole-cell biotransformation of 5-(hydroxymethyl)furfural into FDCA, 2,5furandicarboxylic acid Bioresour. Technol. 1016291

14. McKenna S M, Leimkuhler S, Herter S, Turner N J and Carnell A J 2015 Enzyme cascade reactions: synthesis of furandicarboxylic acid (FDCA) and carboxylic acids using oxidases in tandem Green Chem. 173271

15. Gorbanev Y Y, Klitgaard S K, Woodley J M, Christensen C H and Riisager A 2009 Gold-catalyzed aerobic oxidation of 5-hydroxymethylfurfural in water at ambient temperature ChemSusChem 2672

16. Casanova O, Iborra S and Corma A 2009 Biomass into chemicals: Aerobic oxidation of 5-hydroxymethyl2-furfural into 2,5-furandicarboxylic acid with gold nanoparticle catalysts ChemSusChem 21138

17. Ardemani L, Cibin G, Dent A J, Isaacs M A, Kyriakou G, Lee A F, Parlett C M A, Parry S A and Wilson K 2015 Solid base catalysed 5-HMF oxidation to 2,5-FDCA over Au/hydrotalcites: fact or fiction? Chem. Sci. 64940

18. Lilga M, Hallen R and Gray M 2010 Production of oxidized derivatives of 5-hydroxymethylfurfural (HMF) Top. Catal. 531264

19. Rass H A, Essayem N and Besson M 2015 Selective aerobic oxidation of 5-HMF into 2,5-furandicarboxylic acid with Pt catalysts supported on $\mathrm{TiO}_{2}$ - and $\mathrm{ZrO}_{2}$-based supports ChemSusChem $\mathbf{8} 1206$

20. Davis S E, Houk L R, Tamargo E C, Datye A K and Davis R J 2011 Oxidation of 5-hydroxymethylfurfural over supported Pt, Pd and Au catalysts Catal. Today 160 55

21. Sahu R and Dhepe P L 2014 Synthesis of 2, 5furandicarboxylic acid by the aerobic oxidation of 5hydroxymethyl furfural over supported metal catalysts React. Kinet. Mech. Catal. 112173
22. Gupta N K, Nishimura S, Takagaki A and Ebitani K 2011 Hydrotalcite-supported goldnanoparticle-catalyzed highly efficient base-free aqueous oxidation of 5-hydroxymethylfurfural into 2,5-furandicarboxylic acid under atmospheric oxygen pressure Green Chem. 13824

23. Han X, Geng L, Guo Y, Jia R, Liu X, Zhang Y and Wang Y 2016 Base-free aerobic oxidation of 5-hydroxymethylfurfural to 2,5-furandicarboxylic acid over a Pt/C-O-Mg catalyst Green Chem. 181597

24. Choudhary H and Ebitani K 2016 Hydrotalcitesupported PdPt-catalyzed aerobic oxidation of 5hydroxymethylfurfural to 2,5-furandicarboxylic acid in water Chem. Lett. 45613

25. Casanova O, Iborra S and Corma A 2009 Biomass into chemicals: One pot-base free oxidative esterification of 5-hydroxymethyl-2-furfural into 2,5-dimethylfuroate with gold on nanoparticulated ceria J. Catal. 265109

26. Wan X, Zhou C, Chen J, Deng W, Zhang Q, Yang Y and Wang Y 2014 Base-free aerobic oxidation of 5-hydroxymethyl-furfural to 2,5-furandicarboxylic acid in water catalyzed by functionalized carbon nanotubesupported Au-Pd alloy nanoparticles ACS Catal. 42175

27. Jain A, Jonnalagadda S C, Ramanujachary K V and Mugweru A 2015 Selective oxidation of 5-hydroxymethyl-2furfural to furan-2,5-dicarboxylic acid over spinel mixed metal oxide catalyst Catal. Commun. 58179

28. Ghosh K, Molla R A, Iqubal M A, Islam S S and Islam S M 2016 Ruthenium nanoparticles supported on N-containing mesoporous polymer catalyzed aerobic oxidation of biomass-derived 5-hydroxymethylfurfural (HMF) to 2,5-diformylfuran (DFF) Appl. Catal. A Gen. 52044

29. Antonyraj C A, Jeong J, Kim B, Shin S, Kim S, Lee K-Y and Cho J K 2013 Selective oxidation of HMF to DFF using $\mathrm{Ru} / \gamma$-alumina catalyst in moderate boiling solvents toward industrial production J. Ind. Eng. Chem. 191056

30. Wang F, Jiang L, Wang J and Zhang Z 2016 Catalytic conversion of fructose and 5-hydroxymethylfurfural into 2,5-diformylfuran over SBA-15 supported ruthenium catalysts Energy Fuel 305885

31. Wang F, Yuan Z, Liu B, Chen $\mathrm{S}$ and Zhang Z 2016 Catalytic oxidation of biomass derived 5hydroxymethylfurfural (HMF) over RuIII-incorporated zirconium phosphate catalyst J. Ind. Eng. Chem. 38181

32. Gorbanev Y Y, Kegnaes S and Riisager A 2011 Effect of support in heterogeneous ruthenium catalysts used for the selective aerobic oxidation of HMF in water Top. Catal. 541318

33. Gorbanev Y Y, Kegnaes S and Riisager A 2011 Selective aerobic oxidation of 5-hydroxymethylfurfural in water over solid ruthenium hydroxide catalysts with magnesium-based supports Catal. Lett. 1411752

34. Yi G, Teong S P and Zhang Y 2016 Base-free conversion of 5-hydroxymethylfurfural to 2,5-furandicarboxylic acid over a Ru/C catalyst Green Chem. 18979

35. Mishra D K, Cho J K and Kim Y J 2018 Facile production of 2,5-diformylfuran from base-free oxidation of 5-hydroxymethyl furfural over manganese cobalt spinels supported ruthenium nanoparticle J. Ind. Eng. Chem. 60 513 
36. Mishra D K, Lee H J, Kim J, Lee H S, Cho J K, Suh Y W, Yi Y and Kim Y J $2017 \mathrm{MnCo}_{2} \mathrm{O}_{4}$ spinel supported ruthenium catalyst for air-oxidation of HMF to FDCA under aqueous phase and base-free conditions Green Chem. 191619
37. Yurii V L, Boris L M, Vladimir I Z, Safar M Y, Elena S K, Vladimir B S and Valerii I B 2007 XPS and TEM studies on the role of the support and alkali promoter in $\mathrm{Ru} / \mathrm{MgO}$ and $\mathrm{Ru}-\mathrm{Cs}+/ \mathrm{MgO}$ catalysts for ammonia synthesis J. Phys. Chem. C 1119427 